\title{
PENGARUH RELAKSASI BENSON TERHADAP NYERI PADA PASIEN POST SEKSIO SESARIA DI RSUD KOTA PADANGSIDIMPUAN
}

\author{
Irwan Batubara ${ }^{1}$, Elly Indrani Harahap ${ }^{2}$, Ratni Siregar ${ }^{3}$ \\ Politeknik Kesehatan Kemenkes Medan, Program Studi Kebidanan Padangsidimpuan \\ Sigulang-Pijorkoling Kota Padangsidimpuan \\ Irwanbatubara, 081397897577, irwanbatubara97@gmail.com
}

\begin{abstract}
Abstrak
Relaksasi Benson adalah relaksasi yang dikombinasi dengan keyakinan agama seseorang untuk mengurangi nyeri pada pasien post seksio sesarea (SC). Pengalihan perhatian pada religius dengan perhatian penuh menyadari keberadaan diri dan ketidak berdayaan kecuali atas bantuan dan petunjuk dari Tuhan Yang Maha Esa. Rasa nyeri yang dirasakan post Seksio sesaria akan menimbulkan berbagai masalah, diantaranya masalah laktasi, pasien menunda pemberian ASI sejak awal pada bayinya, karena rasa tidak nyaman/peningkatan intensitas nyeri setelah operasi (Purwandari, 2009). Penelitian ini bertujuan untuk mengetahui pengaruh relaksasi Benson pada pasien post seksio sesarea terhadap rasa nyeri. Quasi expriment one group pre test, post test design. Populasi, Ibu post seksio sesarea yang dirawat di Ruang Bersalin RSUD Kota Padangsidimpuan. Sampel insidental bulan Juli Agustus 2015, berjumlah 48 responden. Analisa data dilakukan uji " $\mathrm{t}$ " berpasangan dengan bantuan SPSS. Hasil Penelitian sebelum intervensi tingkatan nyeri sedang $60,42 \%$ dan sesudah intervensi 29,17\% , Nyeri ringan sebelum intervensi 2,08\% dan terjadi peningkatan sesudah intervensi 70,83. Perhitungan statistik uji t berpasangan dengan kepercayaan $95 \%$ terdapat perbedaan bermakna dengan $p$ value 0,000 . Terdapat pengaruh intervensi teknik relaksasi Benson untuk mengurangi nyeri pada pasien post operasi seksio sesaria. Tim perawatan khususnya bidan menerapkan teknik relaksasi Benson untuk mengurangi insentitas nyeri pada pasien post SC.
\end{abstract}

Kata Kunci : Relaksasi Benson, nyeri post SC

\section{PENDAHULUAN}

Pasien post seksio sesaria akan mengeluh nyeri pada daerah incisi yang disebabkan oleh robeknya jaringan pada dinding perut dan dinding uterus.Prosedur pembedahan yang menambah rasa nyeri seperti infeksi, distensi,spasmus otot sekitar daerah torehan. Rasa nyeri yang dirasakan post seksio sesaria akan menimbulkan berbagai masalah, salah satunya masalah laktasi, pasien menunda pemberian ASI sejak awal pada bayinya, karena rasa tidak nyaman/peningkatan intensitas nyeri setelah operasi (Purwandari, 2009).

Pelatihan relaksasi Benson cukup efektif untuk memunculkan keadaan tenang dan relaks dimana gelombang otak mulai melambat akhirnya membuat seseorang dapat istirahat dengan tenang. Hal ini terjadi ketika subjek mulai merebahkan diri dan mengikuti instruksi relaksasi yaitu pada tahap pengendoran otot dari bagian kepala hingga bagian kaki. Selanjutnya dalam keadaan relaks mulai untuk memejamkan mata, saat tersebut frekuensi gelombang otak yang muncul mulai melambat, dan menjadi lebih teratur. Tahap ini subjek mulai merasakan relaks dan mengikuti secara pasif keadaan relaks tersebut sehingga menekan rasa tegang dan nyeri (Datak, 2008).Keuntungan dari relaksasi Benson selain mendapatkan manfaat dari relaksasi juga mendapatkan kemanfaatan dari penggunaan keyakinan seperti menambah keimanan, dan kemungkinan akan mendapatkan pengalaman tersendiri. Individu yang mengalami ketegangan dan kecemasan yang bekerja adalah sistem saraf simpatis, sedangkan pada waktu relaksasi yang bekerja adalah sistem saraf parasimpatis, dengan demikian relaksasi dapat menekan rasa tegang, cemas, insomnia, dan nyeri (Datak,2008). Hasil studi pendahuluan yang telah dilakukan di RSUD Padangsidimpuan, 2011 tercatat ibu yang melahirkan dengan sectio caesarea berjumlah 1867. Persalinan Seksio ceaseria di RSUD dilakukan dengan beberapa indikasi baik dari faktor ibu maupun dari faktor bayi yang dilahirkan. Faktor ibu diantaranya : riwayat seksio sesaria, ketuban pecah dini, induksi gagal, dan post matur. Faktor janin sebagian besar disebabkan karena presentasi bokong, kelainan letak janin, kelainan plasenta baik plasenta previa maupun solusio plasenta, dan karena gawat janin (fetal distress). 


\section{METODOLOGI PENELITIAN}

Jenis Penelitian ini adalah analitik, one group pre test, post test design, untuk mendiskripsikan intensitas nyeri pasien post seksio sesaria sebelum dan sesudah dilakukan perlakuan teknik relaksasi Benson di RSUD Padangsidimpuan. Rancangan pendekatan pada penelitian ini dapat digambarkan sebagai berikut :

01

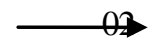

Keterangan :

01 : tingkat nyeri sebelum intervensi relaksasi benson

02 : tingkat nyeri sesudah intervensi relaksasi benson

Tahap intervensi relaksasi Benson:1) Ciptakan lingkungan yang tenang, rileks dan tenang, 2) posisi pasien tidur telentang, 3) anjurkan bernafas dengan irama normal $3 \mathrm{kali}, 4$ ) anjurkan pasien memejamkan mata 2-3 menit untuk menghayati segala sesuatunya dari Allah dan milik Allah setiap melaksanakan point 5, 5) anjurkan pasien mengikuti ucapan peneliti dengan penuh penghayatan, Laa Ilaha Illahloh, Subhanalloh Walhamdulillah Lailaha Illoh, 3 - 5 kali berturut-turut, interval 5 menit anjurkan nafas normal dan 3 kali nafas dalam, 6) ulangi point 5, frekwensi sesuai kemampuan pasien minimal 5 kali, 7) pelaksanaan hari I setelah pasien kooperatif komunikasi, 8) penilaian sebelum dan sesudah perlakuan relaksasi Benson menggunakan Numeric Rating Scale (NRS; Potter 2005).

Populasi Ibu post seksio sesaria yang dirawat di Ruang Bersalin RSUD Kota Padangsidimpuan, teknik pengambilan sampel Insidental bulan Juli - Agustus 2015, berjumlah 48 responden, kriteria inklusi:1). Pasien post operasi seksio hari pertama $12-20$ jam setelah operasi dan kooperatif komunikasi. 2) Pasien gravida 1 dan 2 post seksio sesaria pertama kali, beraga islam. 3). Pasien seksio sesaria dan dirawat di bagian bersalin RSUD Kota Padangsidimpuan.4). Pasien post $\mathrm{S}$ seksio sesaria bayi hidup

Pengumpulan Data dan Analisis Data

Pengukuran intensitas nyeri dilaksanakan sebelum intervensi dan sesudah intervensi menggunakan NRS (Numeric Rating Scale menurut Potter 2005). Skala ukur yang digunakan dijelaskan kepada responden, agar dapat menyebutkan atau menunjukkan insentitas nyeri yang dialami pada skala.

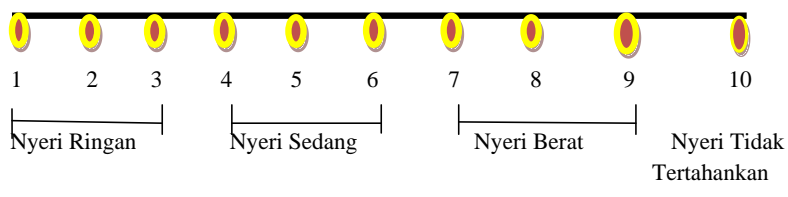

Hasil pengukuran dikumpulkan diolah dengan SPSS, uji “" $\mathrm{t}$ " berpasangan untuk mengetahui perbedaan tingkatan nyeri yang dialami responden sebelum dan sesudah intervensi relaksasi metode Benson.

\section{HASIL PENELITIAN}

Berdasarkan penelitian yang dilakukan terhadap 48 responden yang dirawat di ruang rawat di ruang bersalin RSUD Padangsidimpuan diperoleh hasil:

Tabel 1 Gambaran Tingkat Nyeri Responden Post Seksio Sesaria Sebelum Intervensi Relaksasi Benson

\begin{tabular}{clcc}
\hline No & Tingkatan Nyeri & Responden & $\begin{array}{l}\text { Presentase } \\
(\%)\end{array}$ \\
\hline 1. & Tidak nyeri & - & - \\
2. & Nyeri Ringan & 1 & 2,08 \\
3. & Nyeri Sedang & 29 & 60,42 \\
4. & Nyeri Berat & 18 & 37,50 \\
5. & Nyeri sangat berat & - & - \\
& Jumlah & 48 & 100 \\
\hline
\end{tabular}

Berdasarkan tabel 1 diatas tingkat jumlah responden yang mengalami nyeri sedang sebelum intervensi relaksasi Benson sedang 60,42\%.

Tabel 2 Gambaran Tingkat Nyeri Responden Post Seksio Sesaria Sesudah Intervensi Relaksasi Benson.

\begin{tabular}{clcc}
\hline No & Tingkatan Nyeri & Responden & $\begin{array}{l}\text { Presentase } \\
(\%)\end{array}$ \\
\hline 1. & Tidak nyeri & - & - \\
2. & Nyeri Ringan & 34 & 70,83 \\
3. & Nyeri Sedang & 14 & 29,17 \\
4. & Nyeri Berat & - & - \\
5. & Nyeri sangat berat & - & - \\
& Jumlah & 48 & 100 \\
\hline
\end{tabular}

Dari perbandingan tabel 1 dengan tabel 2 dapat dilihat bahwa terjadi perubahan tingkat nyeri berat $37,50 \%$ sebelum intervensi dan sesudah intervensi relaksasi benson tidak ditemukan lagi, demikian juga kategori nyeri ringan $2,08 \%$ meningkat meningkat $70,83 \%$.

Mengetahui pengaruh teknik relaksasi Benson terhadap penurunan tingkat nyeri pada pasien post seksio sesaria menggunakan Uji t berpasangan.

Tabel 3 Hasil Analisa Pengaruh Teknik Relaksasi Benson Terhadap Tingkat Nyeri Post Seksio Sesaria di Ruang Bersalin RSUD Kota Padangsidimpuan Tahun 2015

\begin{tabular}{|c|c|c|c|c|}
\hline Insentitas Nyeri & Mean & Std & $\begin{array}{l}\text { Beda } \\
\text { Mean }\end{array}$ & $\begin{array}{l}\mathrm{P} \\
\text { Value }\end{array}$ \\
\hline Sebelum & 5,83 & 1,328 & & \\
\hline $\begin{array}{l}\text { Relaksasi Benson } \\
\text { Sebelum Tekknik } \\
\text { Relaksasi Benson }\end{array}$ & 2,85 & 1,321 & 2,98 & 0,00 \\
\hline
\end{tabular}

Tabel 3 menunjukkan penurunan yang cukup signifikan sebelum dan sesudah dilaksanakan teknik relaksasi Benson, rerata bedan mean 2,98. Perhitungan uji t berpasangan dengan kepercayaan $95 \%$ terdapat perbedaan bermakna dengan $\mathrm{p}$ value $0,000(<0,05)$. Artinya terdapat 
pengaruh intervensi relaksasi metode Benson untuk mengurangi nyeri pada pasien post operasi seksio sesaria.

\section{PEMBAHASAN}

Tingkat nyeri responden sebelum intervensi relaksasi metode Benson pasien post seksio sesaria terhadap 48 responden yang dirawat di Ruang Bersalin RSUD Kota Padangsidimpuan, kategori nyeri sedang $60,42 \%$ dan nyeri berat 37,50\% dan setelah intgervensi terjadi penurunan institas nyeri berat beralih kenyeri sedang dan ringan $70,83 \%$.

Pengalihan perhatian pasien dengan ritual ucapan kata Lailaha Illalloh berulang atas dasar keyakinan melibat jiwa, atau psikologis seutuhnya didukung dengan lingkungan yang tenang, perangkat mental (sebuah kata atau frase yang diucapkan secara berulang dalam hati), sikap yang pasif mengesampingkan insitas nyeri. Relaksasi Benson merupakan pengembangan metode repon relaksasi dengan melibatkan faktor keyakinan pasien yang dapat mengurangi nyeri pasca bedah, berfokus pada kata atau kalimat intervensi Lailaha Illalloh, Subhanalloh Walhamdulillah Lailaha Illoh, minimal 5 kali, iterval 5 minit, nafas biasa dan nafas dalam 3 kali. Intervensi dilaksanakan minimal 5 kali interval.

Menurut International Association for Study of Pain (IASP), nyeri adalah sensori subyektif dan emosional yang tidak menyenangkan yang didapat terkait dengan kerusakan jaringan aktual maupun potensial, atau menggambarkan kondisi terjadinya kerusakan. Sayatan pada dinding perut dan uterus untuk melahirkan bayi, placenta menimbulkan rasa nyeri akibat terpusnya serabut syaraf, tekanan akibat jahitan, bendungan cairan pada area luka.

Efek relaksasi Benson mampu membuat tubuh menghasilkan hormon endorphin yang merupakan hormon alami yang diproduksi tubuh manusia dan memiliki fungsi sebagai penghilang rasa sakit secara alami. Endorphin dapat diproduksi tubuh secara alami saat tubuh dalam keadaan rileks seperti latihan pernapasan pada saat interval intervensi dan meditasi. Latihan relaksasi benson juga dapat mengembalikan tubuh ke kondisi yang tenang dan nyaman. Relaksasi ini memberikan efek terhadap peningkatan gelombang alfa sehingga membuat kondisi otak dalam keadaan relaksasi. Ketika mencapai gelombang alfa, otak dalam keadaan tenang dan fokus pada suatu objek, sehingga dapat membangun rasa nyaman terhadap nyeri yang dirasakan. (Benson 2000)

Good (1999) menjelaskan bahwa mekanisme efek relaksasi terhadap nyeri post operasi yaitu menghambat impuls noxius pada sistem kontrol gerbang (gate control theory). Dalam teori kontrol gerbang dari Melzaks dan Wall (1965 dikutip dari Potter dan Perry, 2005) mengusulkan bahwa impuls nyeri dapat diatur atau dihambat oleh mekanisme pertahanan di sepanjang sistem saraf pusat. Mekanisme pertahanan dapat ditemukan di sel-sel substansi gelatinosa di dalam kornu dorsalis pada medula spinalis, talamus, dan sistem limbik (Clancy dan McVicar, 1992 dikutip dari Potter dan Perry, 2005). Teori ini mengatakan bahwa impuls nyeri akan merangsang sel $\mathrm{T}$ di kornu dorsalis kemudian naik menuju medula spinalis dan ke otak ketika gerbang pertahanan terbuka sehingga nyeri dirasakan dan implus nyeri tidak dapat dirasakan atau dihambat ketika gerbang pertahanan tertutup. Upaya untuk menutup pertahanan tersebut merupakan terapi dasar dalam mengurangi nyeri (Potter dan Perry, 2005).

Ketika relaksasi mengalihkan pikiran, talamus akan menengahi perhatian secara selektif ke kortek prefrontal untuk merubah suara-suara terhadap rangsangan nyeri sehingga menghambat impuls nyeri. Kemudian otak sebagai penghambat impuls menutup pintu transmisi pada impuls noxius sehingga impuls nyeri tidak dapat dirasakan atau dihambat (Benson dan Proctor, 2000 dalam Roykulcharoen, 2003) dan alur serabut saraf desenden melepaskan opioid endogen seperti endorfin dan dimorfin sebagai penghambat nyeri alami yang berasal dari tubuh (Potter dan Perry, 2005).

Setelah dilakukan analisis statistik mengenai efektifitas penurunan intensitas nyeri sebelum intervensi dan sesudah intervensi relaksasi Benson menggunakan uji t-test berpasangan, diperoleh nilai $\mathrm{P}$ value sebesar 0,000 yang lebih kecil dari $\alpha$ penelitian $(0,05)$, yang berarti terdapat efektifitas relaksasi Benson terhadap penurunan intensitas nyeri luka post seksio sesaria di Ruang Bersalin RSUD Kota Padangsidimpuan.

Hasil penelitian ini relevan dengan hasil penelitian menggunakan teknik yang sama dalam mengatasi nyeri yang telah dilakukan sebelumnya oleh beberapa peneliti, diantaranya penelitian yang dilakukan oleh Sinta Dewi, A.S., Prof. Dr. dr., dkk (2013) RSUP Sanglah Denpasar Tahun 2014. Dalam penelitian tersebut, bahwa teknik relaksasi Benson dapat menurunkan intensitas nyeri luka post seksio sesaria.

Klien bisa mengungkapkan nyerinya dengan berbagai jalan, mulai dari ekspresi wajah, vokalisasi dan gerakan tubuh. Ekspresi yang ditunjukan klien yang digunakan bidan dalam pengkajian secara teliti apabila klien sedikit mengekspresikan nyerinya, belum tentu orang yang tidak mengekspresikan nyeri itu tidak mengalami nyeri. Kehadiran bidan disamping pasien paska operasi, bersifat komunikatif, membimbing intervensi relaksasi menimbulkan rasa percaya diri, rasanyaman dalam pengalihan rasa nyeri.

Metode relaksasi Benson dengan melibatkan jiwa pasien sepenuhnya dalam pengucapan kata sesuai keyakinan dan dilaksanakan berulang 5-8 kali dapat mengurangi rasa nyeri pada pasien post seksio sesarea yang kooperatif. Tim perawatan membimbing dan melaksanakan teknik relaksasi Benson untuk mengurangi rasa nyeri pasien post seksio sesarea yang kooperatif. 


\section{DAFTAR PUSTAKA}

Arikunto, S. 2003. Prosedur Penelitian: Suatu Pendekatan Praktek . Edisi IV. Jakarta:

Rineka Cipta.

Arrasid. 2007. Studi Kasus Gambaran Penatalaksanaan nyeri pada pasien Tn. H Dengan Post Appendiktomi di Ruang Nusa IndahRSUD Majalengka.

Bruner \& Sudart. 2002. Buku Ajar Keperawatan Medikal Bedah, Jakarta : EGC

Notoatmodjo, S. (2003). Pengantar Kesehatan dan Ilmu perilaku

Pendidikan Jakarta: Rineka Cipta.

Perry, AG, Potter PA .2005. Buku Ajar Fundamental Keperawatan;Konsep, Proses dan Praktik, Vol.2 Alih Bahasa. Editor Monica Ester Dkk, Jakarta : EGC
Priharjo, R. 2003. Perawatan Nyeri. Jakarta. EGC

Sastroasmoro S. 2011. Dasar - dasar Metodologi penelitian klinis. Jakarta.CV.Sagung seto.

Smeltzer \& Bare 2002. Keperawatan Medikal Bedah. Edisi 8. Vol 1. Alih Bahasa Agung Waluyo. Jakarta. EGC

Smeltzer \& Bare 2002. Keperawatan Medikal Bedah. Edisi 8. Vol 2,Jakarta. EGC

Sigit NP. 2010. Konsep dan Proses Keperawatan Nyeri. Edisi 1. Yogyakarta. Graha Ilmu.

Tamsuri A, 2007. Konsep dan Penatalaksanaan Nyeri. Jakarta. EGC

Wicaksono, H. (2004). Ilmu Kebidanan. Edisi 3. Jakarta. Yayasan Bina Pustaka. 